\title{
Breeding Habitat Use of Little Tern along Enshunada Coast-Tenryu River Continuum in Relation to Dam Development
}

\author{
Guangwei Huang \\ Graduate School of Global Environmental Studies, Sophia University, Tokyo, Japan \\ Email: huang@genv.sophia.ac.jp
}

Received 17 February 2015; accepted 9 March 2015; published 12 March 2015

Copyright (C 2015 by author and Scientific Research Publishing Inc.

This work is licensed under the Creative Commons Attribution International License (CC BY).

http://creativecommons.org/licenses/by/4.0/

(c) (i) Open Access

\begin{abstract}
Breeding habitat of the Little Tern in a coast-river continuum was studied in relation to dam development. A habitat shift from coast to river occurred decades after dam construction as the dam-caused coastal erosion became manifested. On the other hand, the riverine habitat was affected by dam both positively and negatively. The positive aspect is the reduction of inundation risk for the habitat, and the negative effect is the vegetation development on the habitat. As a result, the bird did not abandon the riverine habitat although its physical characteristics may be considered as suboptimal. In addition, reasoning was given to explain why an artificially created habitat was not used by the bird. A general message resulting from this study is that species adaptive behaviors should be taken into consideration in assessing environmental impacts caused by human activities such as dam development.
\end{abstract}

\section{Keywords}

Little Tern, Riverine Habitat, Coastal Habitat, Dam, Erosion, Vegetation

\section{Introduction}

Little Tern (Sterna albifrons) is a migratory seabird of the tern family Sternidae, which is $20-28 \mathrm{~cm}$ long, with a wingspan of $45-55 \mathrm{~cm}$ and a weight of approximately $50 \mathrm{~g}$. It is white in color, with pale blue-grey wings and back, and a black cap. This bird breeds on the coasts and inland waterways of temperate and tropical Europe and Asia. Little Tern population has declined or become extinct in many European countries [1] [2], and the loss of inland populations has been even more severe due to dams, river regulation and sediment extraction. In 1994, the species was listed as Species of European Conservation Concern (SPEC), and the status remained unim- 
proved for 10 years after being listed [3]. Garnett classified the Australian breeding population of the Little Tern as vulnerable [4], and the bird is listed as Endangered (Schedule 1, Part 1) in the State of New South Wales under the Threatened Species Conservation Act 1995. A population decline in India was also reported [5]. In Japan, because of its population decline and habitat degradation, this species is listed as "vulnerable" in the Red List by the Ministry of the Environment of Japan.

There are a number of international agreements for the conservation of the Little Tern:

Japan Australia Migratory Bird Agreement (JAMBA): Provides for co-operation between the Governments of Australia and Japan to protect birds which migrate between the two countries. The Little Tern is one of the species listed.

China Australia Migratory Bird Agreement (CAMBA): Provides for co-operation between the Governments of Australia and the People's Republic of China to protect birds which migrate between the two countries. The Little Tern is one of the species listed.

Convention on the Conservation of Migratory Species of Wild Animals (Bonn Convention), which provides a framework for enhancing the conservation status of rare and threatened migratory species throughout their international range.

Convention on Wetlands of International Importance, Especially as Waterfowl Habitat (Ramsar Convention), which promotes the conservation of wetlands and waterfowl.

In keeping these international commitments, the Little Tern has been widely studied for their diet, foraging rhythms, foraging habitat and colony sites [6]-[8]. However, habitat selection by the bird remains insufficiently understood. For instance, it is generally accepted that Little Terns establishes breeding colonies on the bare ground with little vegetation cover [9] [10]. However, [11] showed that Little Terns positively selected for beaches with vegetation. How the bird's preference for non-vegetation substrate might be affected by other factors such as predation avoidance is poorly explored. In North America the Least Tern-a near identical species-has been shown to avoid nesting in areas with high disturbance but otherwise suitable habitat [12]. In Portugal, Little Terns have shifted away from nesting on sandy beaches and instead they are using man-made Salinas. This shift is thought to be linked to human disturbance [13]. To date, Critical Habitat has not been declared for the Little Tern, therefore, more studies to better understand the impacts of disturbance on Little Terns should be pursued [14]. While lacking systematic analyses, countermeasures have been taken in the field. Some colonies of the bird in Japan are now protected for reducing disturbance from people and dogs through fencing, public education and moving nests to safer locations as well.

In light of insufficient understanding on the response of the bird to environmental change, the present study examined the breeding habitat selection by Little Terns through a case study. It was aimed at providing an integrative analysis on the bird's breeding colonies with regard to human disturbance, vegetation and flooding in relation to dam development.

\section{Materials and Methods}

\subsection{Study Site}

The present study focused on the lower reaches of the Tenryu River. Tenryu River originates in the central Honshu Mountains in Japan. From its source at Lake Suwa in Okaya, Nagano Prefecture, it extends 213 km, and drains $5050 \mathrm{~km}^{2}$ into the Enshunada Coast (Figure 1). In length, it is Japan's 9th longest river. There are five dams along the mainstream; Yasuoka Dam, Hiraoka Dam, Sakuma Dam, Akiha Dam and Funagira Dam. The largest one is the Sakuma Dam having a total storage of 326,848,000 $\mathrm{m}^{3}$. Akiha Dam and Funagira Dam were built to regulate water level fluctuations caused by the operation of the Sakuma Dam. Sakuma Dam traps nearly all the sediment load from the upstream of the Tenryu River. Consequently, the Enshunada Coast has significantly receded over the past decades, which implies the degradation of coastal habitat for the bird. The Lower Tenryu River is the portion of the river from the Kashima site to the river mouth. It is now an important habitat for Little Terns in Japan.

A remaining active source of beach-forming sand supply to the coast after the dam construction is the Keta River, which is a tributary of the Tenryu River and located downstream of the four sediment trapping dams but upstream of the Kashima site.

Figure 2 shows the aerial photos of the Lower Tenryu River taken in 1947 and 2003, respectively. It appears clear that the river course has been significantly transformed from a non-vegetated to vegetated channel. The 


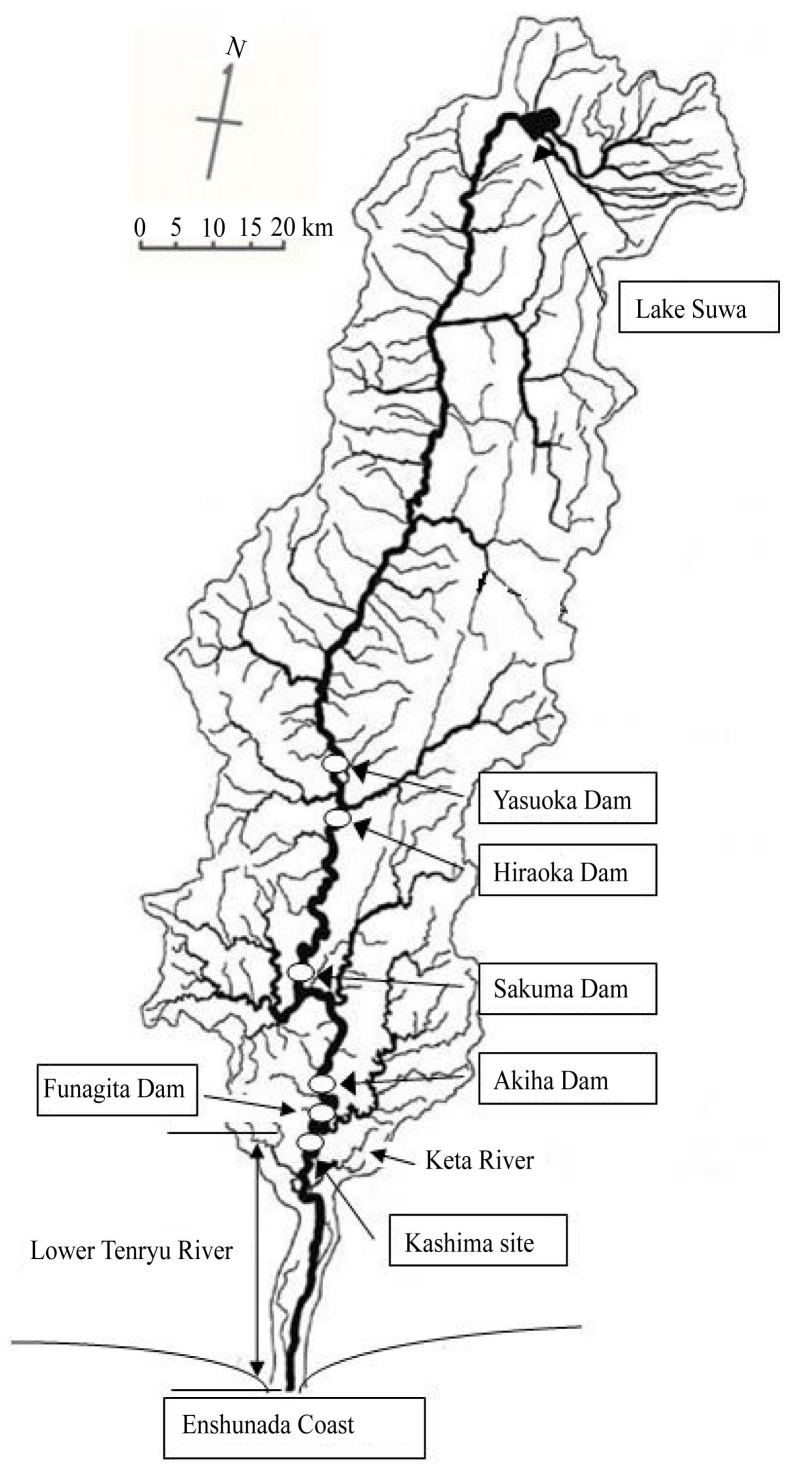

Figure 1. Tenryu River.

dominant plant species are willow and Canada goldenrod. There are a large number of publications on in-channel vegetation dynamics ranging from estimating vegetation-induced resistance, modeling the local alterations of flow and sediment transport by vegetation [15]-[17], and vegetation effects on channel stability and migration [18] [19] to the association with in-stream nutrient dynamics [20]. In this study, the attention was given to the possible impact of in-channel vegetation development upon the bird.

\subsection{Methodology}

This work was designed to examine the impact of dam on the bird's breeding habitat along the river-coast continuum. A new angle of view is to look at the coast and riverine habitats not separately but integratively for the evaluation of dam impact. The hypothesis is that dam may affect coast and riverine habitats differently, causing the birds select one over another. Such an evaluation was made by integrating information for coastal erosion, in-channel vegetation and flow regime alteration that are all induced by dam development with information of bird's habitat use.

According to the survey by the Ministry of Environment, Japan [21], major factors affecting the breeding of the bird include predation, human disturbance, vegetation development and habitat flooding. Along the Lower 


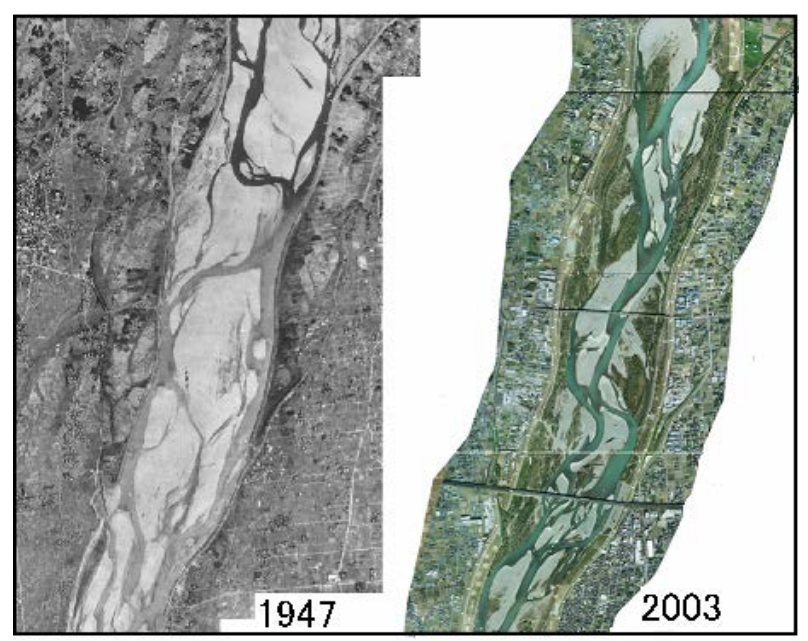

Figure 2. Plan view on the change in Lower Tenryu River.

Tenryu River, Little Terns mainly use middle sandbars as breeding sites where there are virtually no human intrusion and little predation threat as well. The investigation focusing on such sites allows identifying the effects of vegetation and flooding on the bird's selection of habitat with less uncertainty.

Firstly, an interview with a local nonprofit organization-Association for Protection of Marine Community, was conducted to gain information on the bird's behavior decades ago. Then, long-term flow discharge records before and after dam development for the Lower Tenryu River, and in-channel vegetation information were collected from the river management office. The data of in-channel vegetation change were obtained by image processing based on aerial photos taken by the Geospatial Information Authority of Japan over the Tenryu River. The present study visually examined the same aerial photos from the 1960s to the 2000s counting the number of sandbars along the Lower Tenryu River to identify changes of sandbars in the river course over time.

To see the change in flow conditions under which the in-channel vegetation developed, flow discharge records prior to the Sakuma Dam construction and during the period from 1989 to 1999 were analyzed in terms of flow duration curve. The flow-duration curve is a cumulative frequency curve that shows the percent of values that specified discharges were equaled or less than (percentile), or the percent of values that specified discharges were equaled or exceeded (percent exceedance). It is an important means of representing flow characteristics of a stream throughout the range of flow on a single curve.

To quantify how the annual sediment supply from the river to the coast was affected by in-channel vegetation, 12 vegetated sites along the river course were surveyed for their sediment size distributions and deposition depths in order to estimate how much sediment was trapped in vegetated zones. The sampling procedure was to target a $100 \mathrm{~cm} \times 100 \mathrm{~cm}$ square at each survey site. The top surface layer of $5 \mathrm{~cm}$ was removed and discarded in order to eliminate any un-natural disturbance. The next layer of $5 \mathrm{~cm}$ was dug out for sediment size investigation. For those larger than $64 \mathrm{~mm}$, the longest axis was directly measured. For $4 \mathrm{~mm}<$ size $<32 \mathrm{~mm}$, a sieve analysis was performed in the field while for $63 \mu \mathrm{m}<$ size $<4 \mathrm{~mm}$, the size analysis was conducted in the lab with Laser Diffraction Particle Size Analyzer. Once the sample has been analyzed, the results are presented in the form of a cumulative grain size distribution curve. The field visits took place from 2006 to 2012.

Besides, field inspections on substrates of the bird's breeding colonies and their positions relative to water surface edge were carried out.

Results were combined to quantify environmental changes such as vegetation cover and sandbar inundation frequency, and examine how the Little Tern behaved under changing environment. Furthermore, the breeding habitat selection was discussed from the foraging angle. Finally, an integrative view on the breeding habitats of the Little Tern was presented.

\section{Results and Discussion}

\subsection{Costal Habitat}

According to the interview with the nonprofit organization -Association for Protection of Marine Community, 
the Enshunada Coast was used for breeding annually by more than 1000 Litter Terns in the 1980s, but the number of nests on the beach in recent years was grievously decreased. In 2011, as shown in Figure 3, Little Terns arrived at the Niihama beach site on the Enshunada Coast which used to be a breeding habitat for a large number of the birds, yet they did not build nests there. Besides, the number of nests found around the river mouth was just 14 in 2011 according to the report by the Environmental Ministry of Japan [22]. The reason that Little Terns abandoned the coastal breeding colony may be attributed to the coast erosion. As illustrated in Figure 4, the beach erosion progressed significantly along the Enshunda Coast over the past decades. According to [23], the 500-m-terrace offshore of the Tenryu River mouth existed in 1984 had entirely disappeared by 2004. The maximum reduction of beach width along the coast reached to $50 \mathrm{~m}$ [24]. The root cause of the beach erosion is the dam construction in the upstream of the Tenryu River that disrupted sediment supply from the river to the coast. However, a research question is why the erosion manifested more remarkably since the 1990s, which was a long way behind the completion of the Sakuma Dam. A study by Huang indicated that one reason for the time lag between the dam development and coastal erosion was the sediment supply from the river channel bed erosion which was triggered by the sand and gravel mining along the lower reaches of the Tenryu River prior to 1980 [25].

On the other hand, a new mechanism accelerating beach erosion on the Enshunada coast occurred in the 1990s that is in-channel vegetation development. Figure 5 shows the time series of in-channel vegetation area in the Lower Tenryu River. The vegetation growth started in the 1950s and remained more or less the same in the 1970 s, accounting for less than 5\% of the total river channel area. However, there was a big jump in the percentage of the vegetation area during the late 1980s and the1990s. At present, the vegetated area accounts for about $20 \%$ of the total river channel area in the Lower Tenryu River.

Figure 6 shows the representative field results that are measured sediment size distributions on the vegetated floodplain at $14 \mathrm{~km}$ site and on the vegetated sandbar at $5 \mathrm{~km}$ site from the river mouth, respectively. A domi-

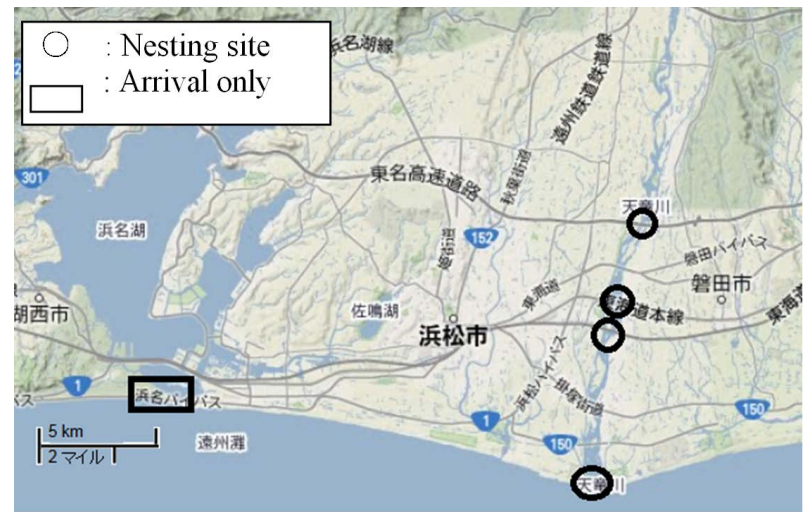

Figure 3. Nesting sites in 2011.

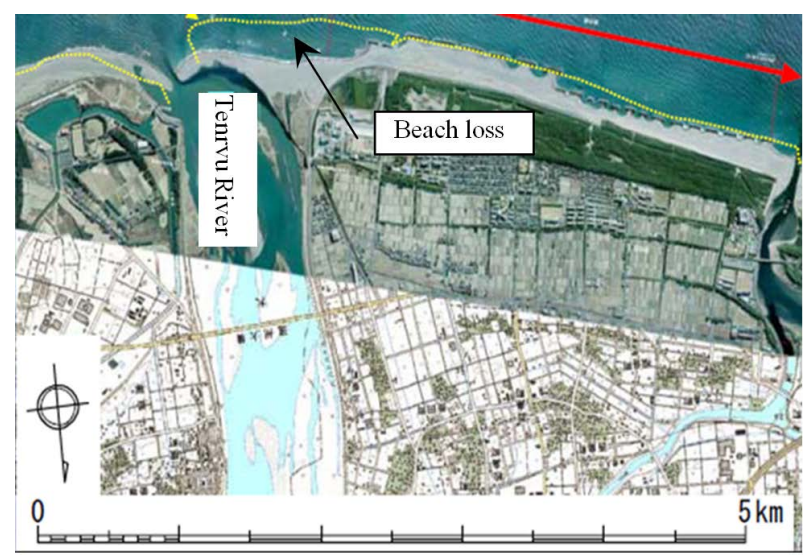

Figure 4. Coastline receding around the river mouth. 


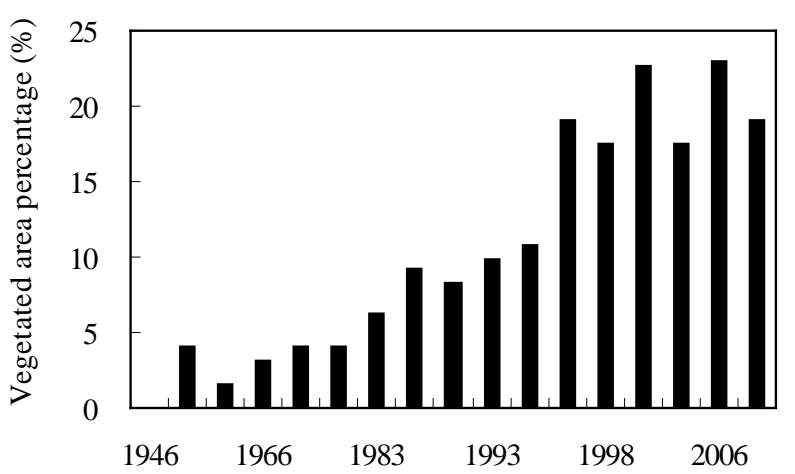

Figure 5. In-channel vegetation development in the Lower Tenryu River.

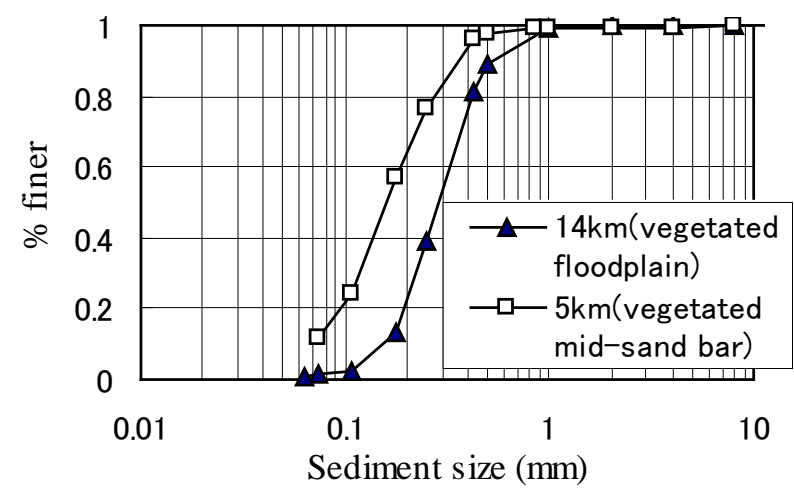

Figure 6. Sediment size distributions in vegetated zones.

nant feature of the results is that a large portion of the Enshunada beach sands $(0.1 \mathrm{~mm}-1 \mathrm{~mm})$ was found in vegetated zones. Based on sediment size distribution and deposition depth, the mean trapping rate for beach-forming sands of the Enshunada coast in the Lower Tenryu River was estimated to be $0.19 \mathrm{~m}^{3} / \mathrm{m}^{2} /$ year from the 12 survey sites. By multiplying this mean trapping rate with the total vegetation area along the Lower Tenryu River, it was inferred that $20000 \mathrm{~m}^{3}$ sands could have been trapped yearly in floodplains and middle bars by vegetation. Besides, by examining sands with polarization microscope, it is clearly seen that beach-forming sands found in vegetated zones are from the Keta River.

A study byTorii et al. estimated that the long-term average of the annual sand supply of this river was $8.0 \times 10^{5}$ $\mathrm{m}^{3} / \mathrm{yr}$ under natural conditions [26]. Uda et al., based on coastal morphological data, estimated that the mean annual sand supply was $65,000 \mathrm{~m}^{3}$ for the period of 1975 to 1985 [27]. Okano et al. reported the simulation result of beach-forming sand flux from the river to the coast as being $11 \times 10^{4} \mathrm{~m}^{3} / \mathrm{yr}$ under current conditions [28]. Compared to these previous findings, it can be stated that the sand trapping by in-channel vegetation in the lower reaches of the river is significant, which further exacerbated the beach erosion. As beach receded, coastal habitat for the Little Tern was diminished.

\subsection{Riverine Habitat in the 1990s}

Little Terns mainly used middle sandbars for breeding in the Lower Tenryu River. Figure 7 shows the variation of the number of nesting sites in the Lower Tenryu River over the past decades. The number in the first half of the 1990s seemed to follow the vegetation growth. However, this should not be interpreted as the bird's preference to vegetation, but indicative of the loss of coastal habitats which led to the concentration of birds in riverine environments.

Figure 8 shows the comparison of flow duration curves before and after the construction of the Sakuma Dam. It can be noticed from this figure that the occurrence of discharges in the range of $2000-8000 \mathrm{~m}^{3} / \mathrm{s}$ had been reduced by a factor of 2. By performing 1-D numerical simulations of river flow with HEC-RAS in the Lower 


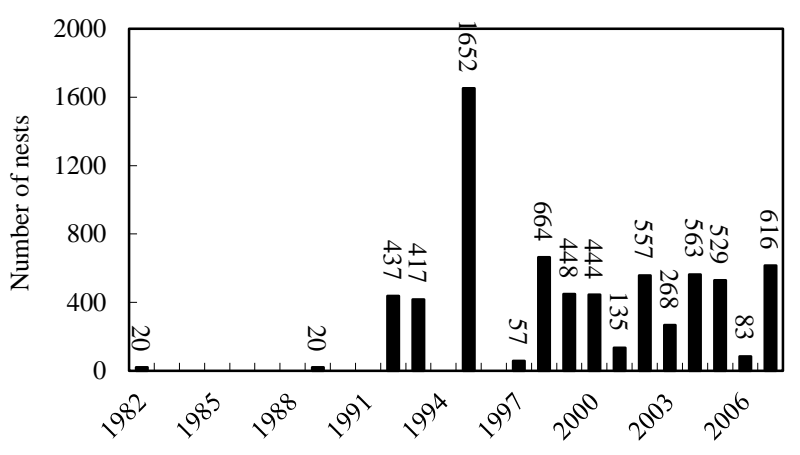

Figure 7. Change in number of nests in the Lower Tenryu River (Source: Bird census of the Ministry of the Environment, Japan).

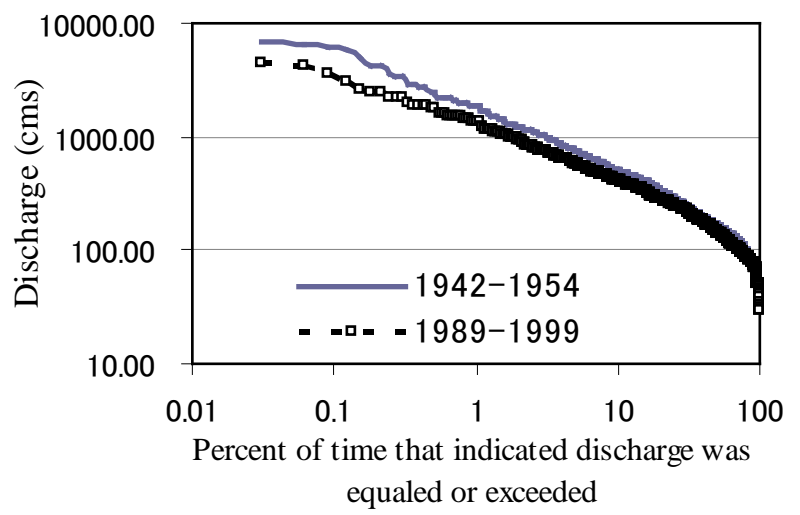

Figure 8. Flow regime change due to dam construction.

Tenryu River, it was found that flows with discharge above $2000 \mathrm{~m}^{3} / \mathrm{s}$ would result in complete inundation of all sand bars, and flows in the range of $1000-2000 \mathrm{~m}^{3} / \mathrm{s}$ would cause partial inundation of sand bars in the Lower Tenryu River. This suggests that the risk that the bird's nests on the sandbars might be washed away by flood waters was significantly reduced in the 1990s. Therefore, the increase in the number of nests for breeding on sandbars in the river during the 1990s in comparison to the 1980s may be attributed to both the loss of coastal habitat and the reduced flooding risk of river sandbars. As shown in Figure 9, the substrates of coastal and riverine habitats are very different. Because the flow reduction and vegetation growth may cause the river channel substrate to shift from coarse materials to fine sediments, habitats similar to the coast habitat might be formed in the river course. This might be considered as a mechanism for Little Terns to use sites with vegetation.

\subsection{Riverine Habitat in the 2000s and Adaptation}

As shown in Figure 10, the number of sandbars in the Lower Tenryu River declined significantly as compared to the 1960s. Besides, the areas of the large sandbars were also shrunken; the area of the largest sandbar in 2006 was just one fourth compared to 1962. Nevertheless, the number of sandbars was stabilized since 1980s and there was even a slight increase in the 2000s.

Considering the fact that the breeding period of Little Terns in Lower Tenryu River is from April to July, the tolerance of Little Terns to the flood characteristics over this breeding period in the 2000s was examined. Figure 11 shows the number of floods having discharge larger than $2000 \mathrm{~m}^{3} / \mathrm{s}$ during the period from April to July and the number of nests in the 2000s. In 2004, 2006, 2007 and 2011, large floods occurred during the breed period. However, the nests of Little Terns were re-established after flooding except 2006. In 2011, all sandbars were inundated three times during the breeding period. Nevertheless, the intervals between these floods were longer than 20 days that is the incubation period for Little Terns. This allowed reestablishment of nests after flooding. In 2006, the number of nests was the lowest while there was just one flood with discharge larger than 

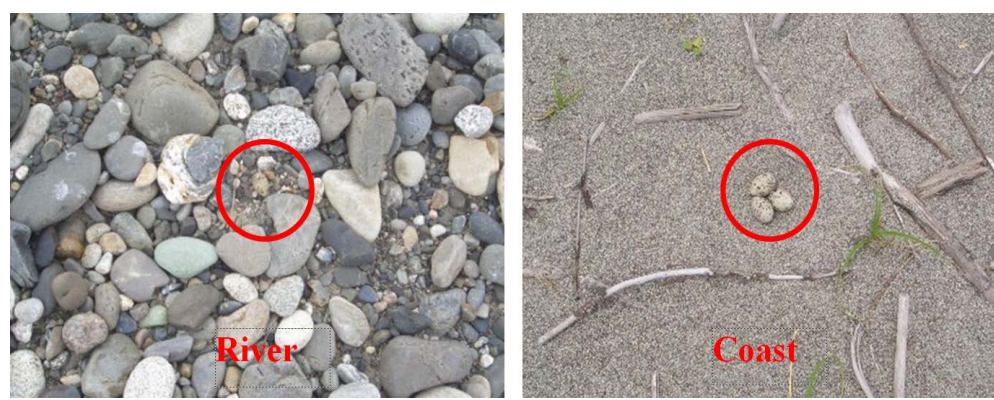

Figure 9. Difference in the substrate of breeding habitat.

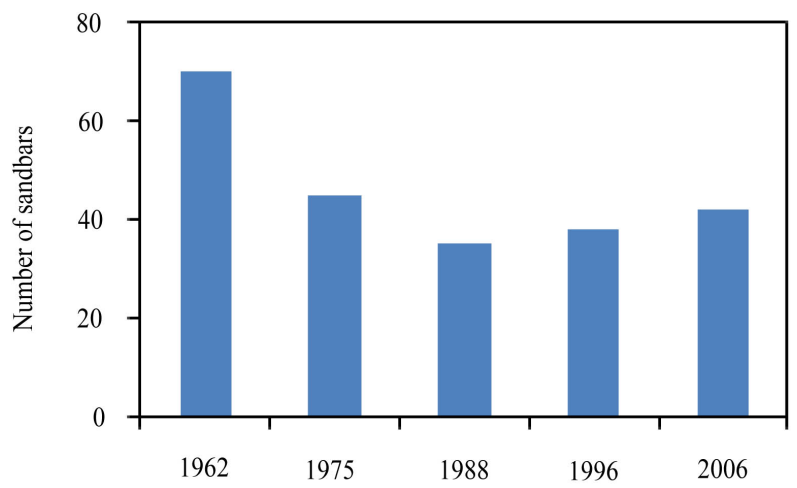

Figure 10. Loss of sandbars in the Lower Tenryu River.

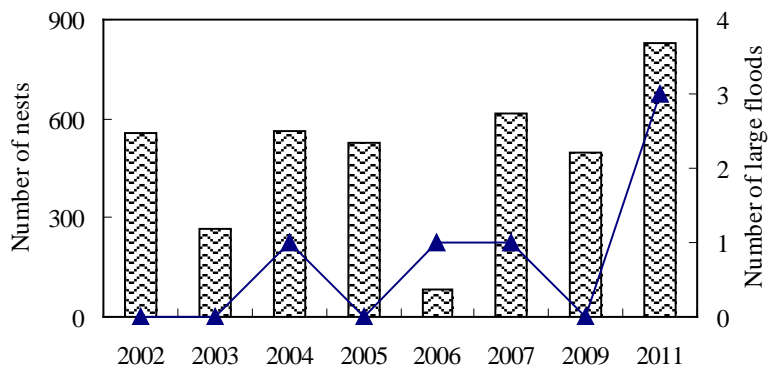

$\propto$ Number of nesting sites $\quad \longrightarrow$ Number of discarge $>2000 \mathrm{~m} 3 / \mathrm{s}$

Figure 11. Effect of flow discharge on the number of nests.

2000. Therefore, factors other than flooding should be sought for the low number of nests. This study hypothesizes that water temperature is the determinant because Little Terns forage on sweat fish (Plecoglossusaltivelisaltivelis) or Ayu in Japanese, and the spring migration of sweat fish from sea to river depends on water temperature [29]. When water temperature is low, they may suspend migration. [30] reported that Ayu's migration was frequently observed when water temperature was the range of $15^{\circ} \mathrm{C}-20^{\circ} \mathrm{C}$. As seen in Figure 12, nests are correlated with the mean water temperature for the period from April to May. The correlation coefficient is 0.75 and $p=0.018<0.05$. In 2006, the mean water temperature was around $12^{\circ} \mathrm{C}$, out of the optimal range for migration.

Field inspection on the edge of vegetation zone and breeding sites revealed that as vegetation zone on sandbars expanded, the birds did not abandon sandbars. Instead, they selected sites away from vegetation but closer to water for breeding. Such a position shift toward water exposes the nests to higher risk of being washed away by floods. This may be viewed as the bird's adaptation to the suboptimal environment under the conditions of the losses of coast habitats and river sandbars. Such a choice of nesting close to water allows individuals to minimize travel time and energy expenditure, and thereby to allocate a greater proportion of time and energy to 
their nestling's needs.

In view of the use of sandbars by Little Terns, local NOPs created an artificial sandbar in the river course. However, this artificial sandbar was not used by the bird. Field inspection revealed that the reason of no adaptation by the bird to such artificial sandbar might be the edge shape of the sandbar. Compared to naturally formed sandbars, the artificial one has a steeper edge as shown in Figure 13. A gentle edge slope will form shallow water areas around the sandbar, which are ideal for foraging because they feed on small fish, often juveniles, and small fish uses shallow waters more frequently than large fish. Besides, it was observed that Little Terns often plunge-dive for food so close to the sandbars ( 2 $\mathrm{m})$ where water depths va

$$
\text { Slope }<\arctan (30 / 200)=8.5
$$

\section{Conclusion}

Based on the afore-explained findings, an integrative picture can be drawn with regard to the breeding habitat for Little Terns in the Enshunada Coast-Tenryu River continuum (Figure 14). The coastal habitat degradation lagged behind the dam construction due to in-channel sand and gravel mining. As sand mining stopped and in-channel vegetation further reduced sediment supply, beach receded significantly, forcing the bird to abandon the coast. On the other hand, dam development altered downstream flow regime reducing the flooding frequency of sandbars in the lower reaches of the Tenryu River. Sandbars free from human disturbance and less inundated, are favorable breeding site to the bird. As a result, Little Terns abandoned the coast and concentrate in the river course and build nests mainly on middle sandbars. Although in-channel vegetation development can be considered as a negative factor, the bird responded to it by moving its nesting sites toward waterline. A lesson learned from this study is that dam, while damaging habitat of a species at one physical environment, might lead to the enhancement of habitat for the same species at another physical environment. Therefore, disappearance of habitat should not be examined in isolation.

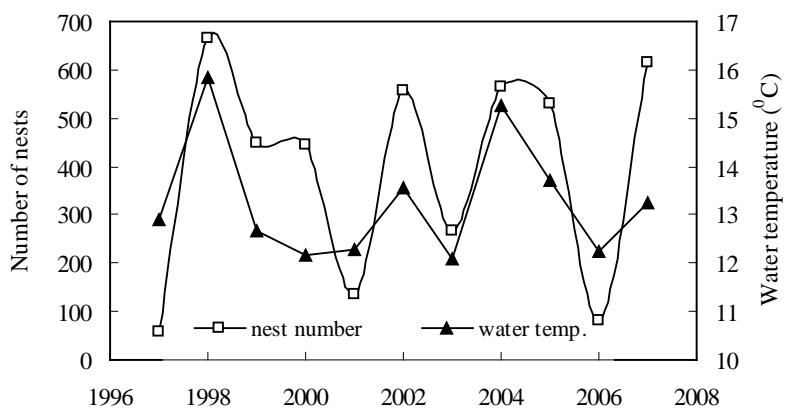

Figure 12. Relation between water temperature and the number of nests.

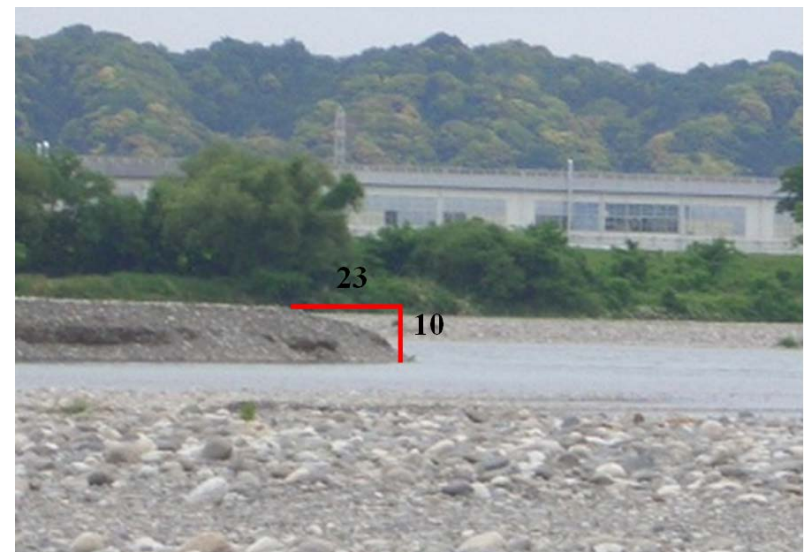

Figure 13. Steep edge of the artificially created sandbar. 


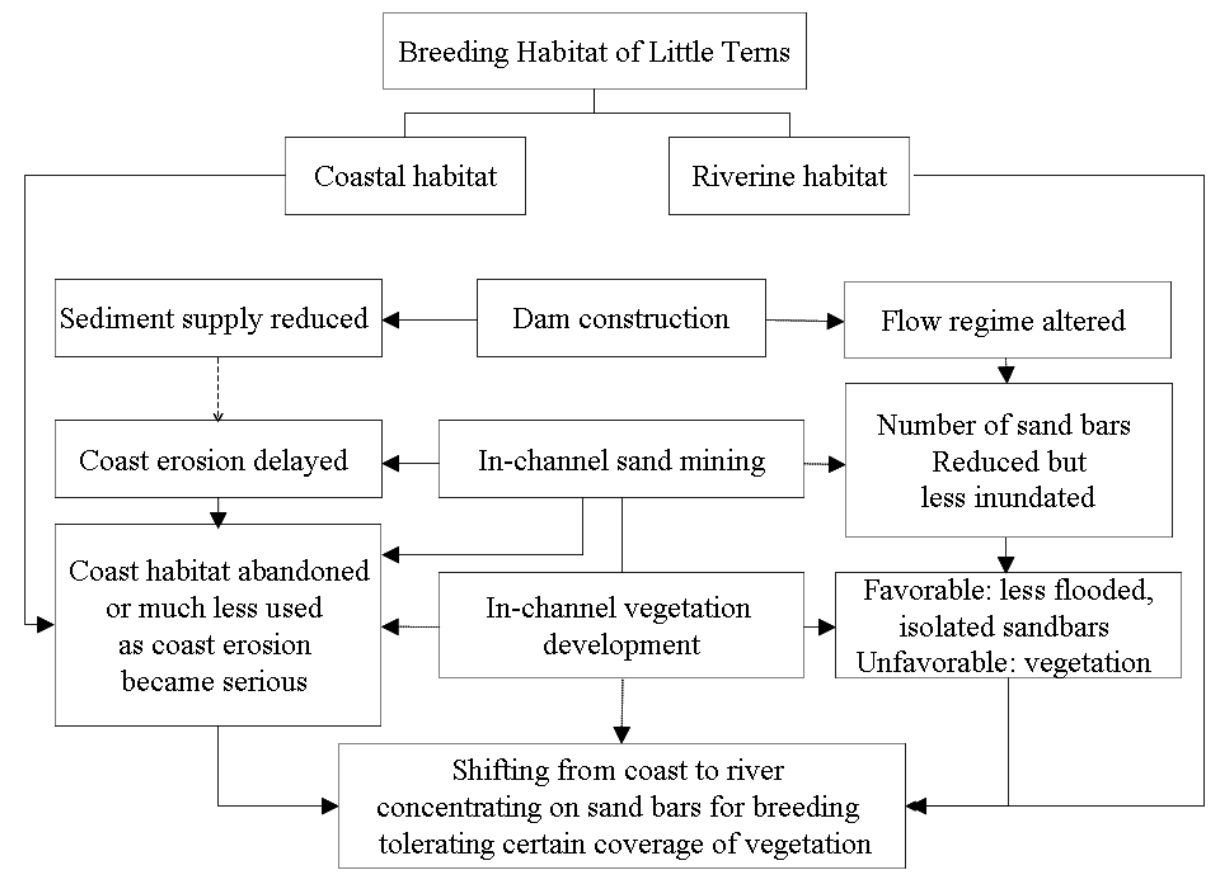

Figure 14. Integrative view on the breeding habitats of the Little Tern.

\section{Acknowledgements}

This work was partially supported by the Overseas Research Fund for Water and Sediment from Qinghua University, China. Thanks should be given to Mr. Yoshii, Mr. Ookubo and Miss Tawarayama, former graduate students of the University of Tokyo, for their involvement and assistance in field works.

\section{References}

[1] Pickerell, G. (2004) Little Tern Sterna albifrons. In: Mitchell, P.I., Newton, S., Ratcliffe, N. and Dunn, T.E., Eds., Seabird Populations of Britain and Ireland, Poyser, London, 339-349.

[2] Scarton, F. (2010) Long Term Decline of a Common Tern (Sterna hirundo) Population Nesting in Salt Marshes in Venice Lagoon, Italy. Wetlands, 30, 1153-1159. http://dx.doi.org/10.1007/s13157-010-0106-y

[3] Burfield, I. and van Bommel, F. (2004) Birds in Europe: Population Estimates, Trends and Conservation Status. Birdlife International, Cambridge, London.

[4] Garnett, S. (1992) Threatened and Extinct Birds of Australia. Royal Australasian Ornithologists Union, Report No. 82, Victoria.

[5] Holloway, M. (1993) The Variable Breeding Success of the Little Tern (Sterna albifrons) in South-East India and Protective Measures Needed for Its Conservation. Biological Conservation, 65, 1-8. http://dx.doi.org/10.1016/0006-3207(93)90189-8

[6] Bogliani, G., Fasola, M., Canova, L. and Saino, N. (1992) Foraging Rhythm and Chick Diet in Little Terns in Three Adriatic Coastal Wetlands. Avocetta, 16, 1-34.

[7] Taylor, I.R. and Roe, E.L. (2004) Feeding Ecology of Little Terns Sterna albifrons sinensis in South-Eastern Australia and the Effects of Pilchard Mass Mortality on Breeding Success and Population Size. Marine and Freshwater Research, 55, 799-808.http://dx.doi.org/10.1071/MF03203

[8] Paiva, V.H., Ramos, J.A., Martins, J., Almeida, A. and Carvalho, A. (2008) Foraging Habitat Selection by Little Terns Sternula albifrons in an Estuarine Lagoon System of Southern Portugal. Ibis, 150, 18-31. http://dx.doi.org/10.1111/j.1474-919X.2007.00722.x

[9] Higgins, P.J. and Davies, S.J.J.F. (1996) Handbook of Australian. New Zealand and Antarctic Birds, Volume 3, Snipe to Pigeons, Oxford University Press, Melbourne.

[10] Fasola, M., Sánchez, J.M. and Roselaar, C.S. (2002) Little Tern Sterna albifrons Account. Birds of Western Palearctic Update, 4, 89-114. 
[11] Ratcliffe, N., Schmitt, S., Mayo, A., Tratalos, J. and Drewitt, A. (2008) Colony Habitat Selection by Little Terns. Sternula albifrons in East Anglia: Implications for Coastal Management. Seabird, 21, 55-63.

[12] Gochfeld, M. (1983) Colony Site Selection by Least Terns: Physical Attributes of Sites. Colonial Waterbirds, 6, 205213. http://dx.doi.org/10.2307/1520989

[13] Catry, T., Ramos, J., Catry, I., Allen-Revez, M. and Grade, N. (2004) Are Salinas a Suitable Alternative Breeding Habitat for Little Terns Sterna albifrons? Ibis, 146, 247-257. http://dx.doi.org/10.1046/j.1474-919X.2004.00254.X

[14] Blumstein, D.T., Fernandez-Juricic, E., Zollner, P.A. and Garity, S.C. (2005) Inter-Specific Variation in Avian Responses to Human Disturbance. Journal of Applied Ecology, 42, 943-953. http://dx.doi.org/10.1111/j.1365-2664.2005.01071.x

[15] Kouwen, N. and Li, R. (1980) Biomechanics of Vegetative Channel Linings. Journal of Hydraulics Division, ASCE, 106, 1085-1103.

[16] Wu, W. and He, Z. (2009) Effects of Vegetation on Flow Conveyance and Sediment Transport Capacity. International Journal of Sediment Research, 24, 247-259. http://dx.doi.org/10.1016/S1001-6279(10)60001-7

[17] Neary, V., Constantinescu, S., Bennett, S. and Diplas, P. (2011) Effects of Vegetation on Turbulence, Sediment Transport, and Stream Morphology. Journal of Hydraulic Engineering, ASCE, 138, 765-776. http://dx.doi.org/10.1061/(ASCE)HY.1943-7900.0000168

[18] Hupp, C.R. (1992) Riparian Vegetation Recovery Patterns Following Stream Channelization: A Geomorphic Perspective. Ecology, 73, 1209-1226. http://dx.doi.org/10.2307/1940670

[19] Burckhardt, J.C. and Todd, B.L. (1998) Riparian Forest Effect on Lateral Stream Channel Migration in the Glacial Till Plains. Journal of the American Water Resources Association, 34, 179-184. http://dx.doi.org/10.1111/j.1752-1688.1998.tb05970.x

[20] Clarke, S.J. (2002) Vegetation Growth in Rivers: Influences upon Sediment and Nutrient Dynamics. Progress in Physical Geography, 26, 159-172. http://dx.doi.org/10.1191/0309133302pp324ra

[21] MOE, Ministry of Environment (2009) Annual Report for Preserving the Little Tern. Nature Conservation Bureau, Ministry of the Environment Government of Japan, Tokyo. (In Japanese)

[22] MOE, Ministry of Environment (2011) Annual Report for Preserving the Little Tern. Nature Conservation Bureau, Ministry of the Environment Government of Japan, Tokyo. (In Japanese)

[23] Uda, T. (2009) Beach Erosion Arising from Anthropogenic Factors. In: Proceedings of Coastal Dynamics, World Scientific, Tokyo, 3-21.

[24] Shizuoka Prefecture (2003) Plan for the Conservation of the Enshunada Coast, Shizuoka. (In Japanese)

[25] Huang, G. (2011) Time Lag between Reduction of Sediment Supply and Coastal Erosion. International Journal of Sediment Research, 26, 27-35. http://dx.doi.org/10.1016/S1001-6279(11)60073-5

[26] Torii, K., Sato, S., Uda, T. and Okayasu, T. (2004) Regional Sediment Management Based on Sediment Budget for Graded Sediments-A Case Study of Tenryu Watershed and Enshu-Nada Coast. Proceedings of the 29th ICCE, Lisbon, 19-24 September 2004, 3110-3122.

[27] Uda, T., Sakano, S. and Yamamoto, K. (1991) Beach Erosion of Enshu-Nada Coast since the 1960s. Report of Public Works Research Institute, No. 183, Tsukuba, 23-70. (In Japanese)

[28] Okano, M., Yasuda, Y. and Mori, K. (2003) Study on the Influence of the Dam Reservoirs in Tenryu Middle Stream on the Whole Sediment-Flow System in the Basin. Report of Water Resources Environment Research Institute, 26-37. (In Japanese)

[29] TFES (Tokyo Fisheries Experimental Station). Migration Ecology of Ayu in Tama River, Tokyo. (In Japanese)

[30] Hirano, K., Iwatsuki, Y., Mimura, F., Magi, M. and Oda, S. (1996) Time of Upstream Migration of Ayu, Plecoglossusaltivelis, in the Gokase River. Aquaculture Science, 44, 1-6. (In Japanese) 